занятости, учебные курсы в общеобразовательных школах и учебных заведениях, а также через система профсоюзного образования.

$$
* * *
$$

1. Гусева Т.С. Правовое регулирование пособий по безработице: международные стандарты, зарубежный опыт, российская действительность // Российская юстиция. - 2011. - №2. - С. 78.

2. Даньшина Д. Н. Проблемы безработицы в Российской Федерации // Молодой ученый. - 2016. №6.6. - С. 64-65.

3. Грик, Н. А. Занятость населения и ее регулирование: Учебно-методическое пособие [Электронный ресурс] / Н. А. Грик. - Томск: ТУСУР, 2007. - 34 с

4. Днепров М.Ю. Основы экономической теории: учебник для СПО/ М.Ю.Днепров, В.А.Николаев.М.: Юрайт, 2019.- 216.c.

5. Гришанова С.В. Внешние эффекты производства // Никоновские чтения. - 2011. - № 16. - С. 66.

\title{
Хаджимурадова T.X. \\ Понятие и место института льгот в системе права социального обеспечения
}

ФГБОУ ВО Чеченский государственный университет

(Россия, Грозный)

doi: 10.18411/lj-04-2021-317

Аннотация

Актуальность данной темы обусловлена тем, что система социального обеспечения в России является многоуровневым и важным направлением поддержки граждан.

Ключевые слова: социальное обеспечение, льготы, социальное страхование.

\footnotetext{
Abstract

The relevance of this topic is due to the fact that the social security system in Russia is a multi-level and important area of support for citizens.

Keywords: social security, benefits, social insurance.
}

Основным государственным органом, занимающимся социальным обеспечением в России, является Министерство труда и социальной защиты Современная система социального обеспечения в Российской Федерации сформировалась в переходный период после распада СССР в 1991 году.

Социальное обеспечение включает три основных формы социальной защиты социальное страхование, социальная поддержка и социальная служба. Социальное страхование включает в себя: пенсионное страхование, медицинское страхование и производственное страхование, страхование от несчастных случаев (охрана труда и техника безопасности). Взносы социального страхования в России уплачиваются в виде «обязательных страховых взносов на пенсионное страхование, социальное страхование и медицинское страхование для каждого работника (персонифицированные взносы), а также через взносы на обязательное социальное страхование от несчастных случаев на производстве и профессиональных заболеваний» [ 1, с.131].

Страховые взносы взимаются с компаний, индивидуальных предпринимателей и физических лиц, производящих платежи другим лицам в рамках трудовых отношений и в соответствии с гражданскими договорами на оказание услуг или выполнение работ, а также на основании других конкретных видов договоров. Взносы также взимаются с индивидуальных предпринимателей, в том числе индивидуальных предпринимателей, нотариусов, а также юристы. Никакие обязательные взносы не уплачиваются сотрудниками.Что касается социальной поддержки, то она ориентирована в основном для социально уязвимых групп населения. Социальная поддержка реализуется через 
социальные службы. Система социального обеспечения охватывает следующие категории граждан: пенсионеры, люди с ограниченными возможностями; дети - семьям с детьми предоставляются различные пособия, в том числе декретный отпуск; семьи с более чем тремя детьми; семьи с низким доходом; молодые семьи; ветераны войны; безработные [2, с.98].

Что касается выплат по социальному обеспечению, то есть два основных фонда финансирования социального обеспечения: фонд социального страхования; пенсионный фонд Российской Федерации. Оба финансируются за счет обязательных взносов социального страхования и личных добровольных взносов. Обязательные взносы вычитаются работодателем только из заработной платы иностранных граждан со статусом постоянного или временного проживания, а не иностранцев, временно проживающих и работающих в России, поскольку для этого типа работников права на эти пособия отсутствуют.

Только российские граждане имеют право на все виды государственной поддержки. Исключением является неотложная медицинская помощь, которая доступна всем в стране по гуманитарным соображениям.В дополнение к этому, иностранные граждане, которые имеют статус постоянного или временного проживания, могут также иметь право на другие льготы в некоторых случаях. Пособия по безработице, дополнительные медицинские пособия или пенсии могут предоставляться экспатриантам с постоянным или временным видом на жительство, которые заплатили в эти фонды. Тем, кто имеет долгосрочные цели жить в России, целесообразно сделать взносы в соответствующие фонды, поскольку это дает право на получение этих льгот и получение пенсии. Тем не менее, правила об этом в настоящее время находятся в состоянии изменения и должны быть проверены с работодателем или с соответствующим государственным департаментом.

«Льготы в праве социального обеспечения выступают основными юридическими средствами, которые ориентированы на реализацию социальнообеспечительных отношений, для субъектов, а именно граждан, находящихся в трудной жизненной ситуации. Данные средства направлены на облегчение положения уязвимых граждан с помощью средств полного или частичного освобождения от исполнения установленных обязанностей» [ 3,c.165].Основаниями (социальноправовые) для предоставления льгот по системе социального обеспечения выступает объективно возникшие жизненные ситуации (инвалидность, старость, малообеспеченность и др.), в результате порождающие специфические потребности личности (в специальных средствах передвижения, в бытовом обслуживании на дому и др.). Поэтому дополнительные права в виде льгот, обеспечивают этим лицам возможность хоть и не в полной, но зато частичной мере удовлетворять свои основные жизненные потребности на необходимом уровне.

Наиболее благоприятным фактором предоставления гражданам льгот являются наличие у граждан особых заслуг перед обществом. Предоставление льгот по этому основанию является не только потребностью лица в особых формах социальной защиты ввиду инвалидности, старости и др., но и служит формой поощрения и признания заслуг перед обществом и государством (инвалиды и участники ВОВ, инвалиды боевых действий на территории других государств и др.). Эти льготы можно назвать привилегиями. Привилегии имеют смысл, когда существует дефицит услуг, большая очередь на предоставление услуг. В будущем, когда социальные услуги не будут дефицитными, подобные привилегии перестанут существовать.Льготы имеют сходство с привилегиями, поскольку и те, и другие являются исключениями из общих правил. 
Из анализа различных источников, льготу можно рассматривать как:

— право, иммунитет или выгода, которыми пользуется только лицо, помимо преимуществ большинства.

- специальное право, иммунитет или освобождение, предоставляемые лицам, находящимся во власти или должности, чтобы освободить их от определенных обязательств или обязательств.

- предоставление частному лицу, корпорации и т. д. особого права или иммунитета при определенных условиях.

— принцип или условие пользования особыми правами или иммунитетами $[4, \mathrm{c} .87]$.

Льгота как форма социального обеспечения - довольно специфическое явление в законе социального обеспечения. Долгое время в науке о праве социального обеспечения тема льгот оставалась вне поля внимания ученых, хотя в рамках общей теории права такой элемент механизма правового регулирования был проанализирован многими авторами.

Социальная льгота представляет собой социальное преимущество для нуждающихся граждан. Социальные преимущества определены очень широко, и не всегда требуется, чтобы пособие было связано с трудовыми отношениями. Это все те преимущества, которые, независимо от того, связаны ли они с трудовым договором или нет, обычно предоставляются работникам, главным образом, из-за их объективного статуса в качестве работников. Можно выделить основные признаки преимуществ: исключение из общепринятых правил; законные исключения, правовые исключения, установленные компетентными органами; привилегии сопровождаются более полным удовлетворением интересов субъектов, облегчением условий их жизни [5, с.18].Государство в своей политике исходит из того, что алиментарные потребности граждан должны быть удовлетворены. Те, кто не в состоянии сделать это самостоятельно, вправе обратиться за помощью к государству, и такая помощь должна быть им предоставлена.

Таким образом, бесспорным принципом демократического общества является то, что каждый человек обязан обеспечить свое существование сам. Но в любом обществе живут люди, которые от рождения, по причине болезни или старости не в состоянии это сделать. Недостаточно предприимчивые люди, люди с ограниченными физическими возможностями, многодетные граждане часто оказываются нуждающимися, инвалиды требуют ухода и лечения и т. д. Общество не может бросить таких людей на произвол судьбы, поэтому оно создает государственную систему их материального обеспечения. Человеческая солидарность и гуманизм реализуются именно в этих действиях государства. Поэтому на уровне основного закона государства в Конституции РФ закреплено право на социальное обеспечение и защиту.

$$
* * *
$$

1. Землянухина Н.С. Льготы отменить нельзя сохранить// Вестник Астраханского государственного технического университета. 2006. № 3. С.131.

2. Аракчеев В.С. Теоретические и практические вопросы общей части права социального обеспечения. Томск, 2010. - 98 с.

3. Климов И.А. Реформа социальных льгот в оценках россиян. // Журнал исследований социальной политики. 2006.№ 3. - С.165.

4. Крылатых Е.Г. Льготы в советском праве социального обеспечения: Автореф. ... дисс. канд. юрид. Наук. М.,87 с.

5. Морозова И.С. Проблемы оптимизации процесса «монетизации» натуральных преимуществ в Российской Федерации//Журнал российского права. 2005. №8. - С. - 18. 